\title{
Gonad development in females of fiddler crab Uca rapax (Crustacea, Brachyura, Ocypodidae) using macro and microscopic techniques
}

\author{
Daniela da Silva Castiglioni ${ }^{1}$, Maria Lucia Negreiros-Fransozo ${ }^{2}$, Laura S. López Greco ${ }^{3}$, Aron F. \\ Silveira $^{4} \&$ Sérgio O. Silveira ${ }^{4}$
}

1. Laboratório de Carcinologia, Departamento de Zoologia, Universidade Federal do Rio Grande do Sul. Av. Bento Gonçalves, 9500, bloco IV, Prédio 43435, 91501-970 Porto Alegre, RS, Brazil. (danielacastiglioni@ yahoo.com.br)

2. Departamento de Zoologia, Instituto de Biociências, Caixa Postal 510, UNESP, 18618-000 Botucatu, SP, Brazil.

3. Departamento de Biodiversidad y Biología Experimental, FCEyN, Pab. II, Universidad de Buenos Aires, Ciudad Universitaria, C1428 EHA, Buenos Aires, Argentina.

4. Departamento de Histologia, Laboratório de Histologia, Universidade Federal de Santa Maria, 97105-900 Santa Maria, RS, Brazil.

\begin{abstract}
The morphology of the ovaries in Uca rapax (Smith, 1870) was described based on macroscopic and microscopic analysis. Females were collected in Itamambuca mangrove, Ubatuba, state of São Paulo, Brazil. In the laboratory, 18 females had their ovaries removed and prepared for histology. Each gonad developmental stage was previously determined based on external and macroscopic morphology and afterwards each stage was microscopically described. The ovaries of $U$. rapax showed a pronounced macroscopic differentiation in size and coloration with the maturation of the gonad, with six ovarian developmental stages: immature, rudimentary, developing, developed, advanced and spent. During the vitellogenesis, the amount of oocytes in secondary stage increases in the ovary, resulting in a change in coloration of the gonad. Oogonias, primary oocytes, secondary oocytes and follicular cells were histologically described and measured. In female's ovaries of $U$. rapax the modifications observed in the oocytes during the process of gonad maturation are similar to descriptions of gonads of other females of brachyuran crustaceans. The similarities are specially found in the morphological changes in the reproductive cells, and also in the presence and arrange of follicle cells during the process of ovary maturation. When external morphological characteristics of the gonads were compared to histological descriptions, it was possible to observe modifications that characterize the process in different developmental stages throughout the ovarian cycle and, consequently, the macroscopic classification of gonad stages agree with the modifications of the reproductive cells.
\end{abstract}

KEYWORDS. Macroscopic analysis, histological analysis, oogonias, primary and secundary oocytes, Uca rapax.

RESUMO. Desenvolvimento da gônada em fêmeas do caranguejo-violinista Uca rapax (Crustacea, Brachyura, Ocypodidae) utilizando técnicas macro e microscópicas. A morfologia dos ovários de Uca rapax foi descrita baseada nas análises macroscópica e microscópica. As fêmeas foram coletadas no manguezal de Itamambuca, Ubatuba, Estado de São Paulo, Brasil. No laboratório, os ovários de 18 fêmeas foram retirados e preparados para histologia. Os estágios gonadais foram caracterizados previamente por meio de análises da morfologia externa e macroscopia e posteriormente cada estágio foi descrito microscopicamente. Os ovários das fêmeas de $U$. rapax apresentaram uma diferenciação macroscópica pronunciada no tamanho e coloração durante o processo de maturação, sendo caracterizados seis estágios de desenvolvimento ovariano: imaturo, rudimentar, em desenvolvimento, desenvolvido, avançado e esgotado. Microscopicamente, estes estágios diferiram quanto ao tamanho, cor e proporção de oogônias e oócitos presentes. Na análise histológica, oogônias, oócitos primários e secundários e células foliculares foram descritos e mensurados. As modificações observadas nos oócitos durante o processo de maturação dos ovários das fêmeas de $U$. rapax são similares às descrições de gônadas de outras fêmeas de braquiúros. As semelhanças foram especialmente observadas nas mudanças morfológicas das células reprodutivas e, também no arranjo das células foliculares durante o processo de maturação ovariana. Quando as características morfológicas externas das gônadas foram comparadas com as descrições histológicas, foi possível observar modificações que caracterizam o processo em diferentes estágios de desenvolvimento do ciclo ovariano e conseqüentemente, a classificação macroscópica das gônadas coincide com as modificações nas células reprodutivas.

PALAVRAS-CHAVE. Análise macroscópica, análise histológica, oogônias, oócitos primários e secundários, Uca rapax.

Reproductive cycles of a crustacean include a series of morphological and physiological events. In specimens completing the juvenile stages, these events include proliferation of gonial cells (activation of gametogenesis), differentiation and growth of gametes to maturation (gamete production), reproductive behavior associated with mating, release of gametes; ovulation, spawning, and incubation of embryos until hatching to release larvae or juveniles (GIESE \& PeArse, 1974; SAstry, 1983). This cycle is basic to all sexually reproducing crustaceans, but the time relationship between certain events and duration of these events varies for different species (SASTRY, 1983).

The process of oogenesis is quite similar for most decapods, but the period and frequency of oogonic cycles vary greatly from a few days to 2 years for other species. The reproductive traits as the rate of oocyte growth, the amplitude of ovarian growth, the frequency of oogenic cycles, the timing within the year and the number of oogenic cycles during one intermolt period appears to be specific. As reported by SASTRY (1983), all these aspects have important consequences to the reproductive ecology of species.

During the course of gonad maturation the ovaries undergo a sequence of macroscopic changes in its morphology (mainly in its relative size), which are easily detectable by a naked-eye (AdiYodi \& Subramonian, 1983; Meusy \& CharniauX-Cotton, 1984; Arculeo et al., 1995). The change in colour is the result of modifications in carotenoid content occurring during the oogenesis, which play an important role during embryogenesis (Goodwin, 1951). 
The macroscopic characterization of the gonads among decapods has been commonly investigated by several authors. Most of the papers dealing with the determination of the onset of the sexual physiological maturity or histological maturity, taking into account the degree of gonad development (COSTA \& NEGREIRosFransozo, 1998; PinHEIRO \& FRANSOZO, 1998; LÓPEZ-GRECO \& Rodríguez, 1999a; Santos \& Negreiros-Fransozo, 1999; Castiglioni \& Santos, 2001; Swiney \& Shirley, 2001; Flores et al., 2002; CAstiglioni \& NegreirosFransozo, 2006 among others). However, studies of histological description of gonads are less common (Cronin, 1947; Adiyodi \& Subramonian, 1983; Meusy \& CharniauX-Cotton, 1984; Wenner et al., 1987; Krol et al., 1992; LóPEZ et al., 1997; ANDO \& MAKIOKA, 1998), the majority being on Caridea and Penaeoidea (RoDRíGUEZ, 1985; Tan-Fermin \& Pudadera, 1989; Quinitio \& Millamena, 1992; Moraes, 1994; Quintero \& Gracia, 1998; Oliveira et al., 1999; PALAcios et al., 1999; SAKAJI et al., 2000; SAKaJi, 2001; Mossolin \& Bueno, 2002 and DUMONT \& D'INCAO, 2004).

The fiddler crab Uca rapax (Smith, 1870) is one of the most abundant species, living in burrows excavated in coarse wet sediment in mangrove habitats along the northern coast of the state of São Paulo, Brazil. It occurs from Florida south through the Gulf of Mexico, Antilles, and Venezuela to Brazil (from states of Pará to Santa Catarina) (Melo, 1996). Although many aspects of this species' behavior, physiology, growth and populational biology are known (SALMON, 1971; GREENSPAN, 1980; McNAMARa \& Moreira, 1983; GeNONI, 1985, 1991; SALMON \& KetTler, 1987; Zanders \& Rojas, 1996a,b,c and CAstiglioni \& Negreiros-Fransozo, 2004a, b, 2005), scarce information is available on its reproduction (CASTIGLIONI \& Negreiros-Fransozo, 2006; CAstiglioni et al., 2006). This paper was accomplished in order to match data from macroscopic and microscopic analysis of females' gonad development of $U$. rapax in order to check the validity of the macroscopic technique.

\section{MATERIAL AND METHODS}

Fiddler crabs were obtained in April 2002 at Itamambuca mangrove, Cavalo river $\left(23^{\circ} 24^{\prime} \mathrm{S}\right.$ and $\left.45^{\circ} 00^{\prime} \mathrm{W}\right)$, Ubatuba, state of São Paulo, Brazil. For sampling we used the procedure of capture per unit effort (cpue), by two collectors during $15 \mathrm{~min}$. at low tide periods. In the studies performed by CASTIGLIONI \& NegreirosFransozo (2004a) and CASTIGLIONI \& Negreiros-Fransozo (2006), it was observed that the females of $U$. rapax attained the morphologic and physiologic sexual maturity with $12.1 \mathrm{~mm}$ of carapace width (CW) (size in which $50 \%$ of females can be considered sexually mature).

Collected crabs were sorted and packed in labeled plastic bags and were maintained during $30 \mathrm{~min}$. in a freezer to be anesthetized. Afterwards, the gonad developmental stages in females were analyzed removing the carapace of the specimens on the dorsal region. The shape, size and coloration were analyzed and classified in 6 stages of development (macroscopic maturity criterion): immature, rudimentary, developing, developed, advanced and spent, following a modification of the procedures proposed by HAEFNER (1976), CHOY (1988), Abelló (1989) and Negreiros-FrANSOZO et al. (2002).

A total of 18 females (3 at each stage of gonad development) larger than $12.1 \mathrm{~mm}$ of $\mathrm{CW}$ were processed for microscopic characterization of the ovaries. Each female was sacrificed and the gonads were quickly dissected and fixed in Bouin's solution for 24 hours at $20^{\circ} \mathrm{C}$. Afterwards, the gonads were dehydrated through an alcohol series (80\%, $90 \%$ and $95 \%$ - one hour in each). Gonads were placed and kept for two hours in a preinfiltration solution and transferred to an infiltration solution for three to four hours or overnight. In the following day, blocks were made using a blocking solution and an accelerator. Finally, the gonads were embedded in resin, the sections were prepared using a microtome (3 to $4 \mu \mathrm{m})$, stained using haematoxylin-eosin (3 $\mathrm{min}$.), and mounted in slides using Entelan.

Cell types found in the ovary of $U$. rapax were described, and for each macroscopical stage histological descriptions were also accomplished. Diameter of germinative cells (oogonias and oocytes) show in the ovaries was measured (largest and smallest diameter) and a mean of the two diameters obtained for each cell was calculated. They were measured by means of a micrometric ocular lens, calibrated against a Leitz Wetzlar plate with $10 \mu \mathrm{m}$ spacing.

\section{RESULTS}

Female's reproductive system in $U$. rapax follows the anatomical pattern observed in Brachyura. They have pair ovaries (dorsum-lateral to the digestive system) and connected in the middle, showing an " $\mathrm{H}$ " shape.

Different cellular types were observed during the ovary development of $U$. rapax, as follows:

Oogonia: these cells are characterized by the presence of young germinative cells that are grouped in the center of the ovary. This type of cell shows a disperse chromatin attached to the nuclear membrane and a basophilic cytoplasm (Fig. 1). Oogonia diameter ranged from 10.0 to $22.5 \mu \mathrm{m}$ with a mean ( \pm standard deviation) of $16.1 \pm 3.0 \mu \mathrm{m}$.

Primary oocytes (pre-vitellogenics): these cells are found generally close to the oogonia. Early primary oocytes have a basophilic homogeneous cytoplasm without follicle cells. Late primary oocytes have a heterogeneous cytoplasm that presents small vacuoles. The cytoplasm of late primary oocytes is less basophilic than the cytoplasm of early primary oocytes. Late oocytes are surrounded by follicle cells that are round in shape (Fig. 1 and Fig. 2). Pre-vitellogenic oocytes have a well defined nucleus with prominent nucleoli on the border, and a dispersed chromatin attached to the nuclear membrane. The size of the primary oocytes ranged from 40 to $80 \mu \mathrm{m}(59.1 \pm 9.1 \mu \mathrm{m})$.

Secundary oocytes (vitellogenics): these cells are acidophilic, showing high content of yolk and lipid drops. In these cells, nucleus:cytoplasm ratio is very low. All vitellogenic oocytes are surrounded by flat follicle cells that allowed the observation of the complete process of follicle formation (Fig. 2). The vitellogenic oocytes showed a size range from 160 to $280 \mu \mathrm{m}$ in diameter $(224.8 \pm 35.3 \mu \mathrm{m})$ (Fig. 3 ). 
The macroscopic and microscopic evaluation of female gonads of $U$. rapax enabled the ovaries to be grouped into five distinct developmental stages, characterized as follows:

Rudimentary: undeveloped, thin, and transparent gonads with a filamentous aspect. In this stage oogonias were numerous and surrounded by follicle cells and the primary and secondary oocytes cannot be observed and the animal is physiologically classified as immature.

Developing: ovary coloration yellow to orangereddish. Gonad: hepatopancreas ratio is about 1:10. Oogonias and pre-vitellogenic oocytes could be observed at this phase surrounded by follicle cells. In this stage, a small number of vitellogenic oocytes could be observed. Oogonias are grouped and oocytes are dispersed in the ovary (Fig. 3).

Developed: ovary with a lobate shape and dark red coloration. Gonad: hepatopancreas ratio is about 1:2. Oogonia and pre-vitellogenic oocytes could be observed in the histological analysis. The oocytes showed a homogenous and basophilic cytoplasm, chromatin located on the borders of the cell, and only one nucleolus in the first stages of primary vitellogenesis. These previtellogenic oocytes are starting to be surrounded by follicle cells. In well developed pre-vitellogenic oocytes, the cytoplasm is less basophilic with lipid drops. In these

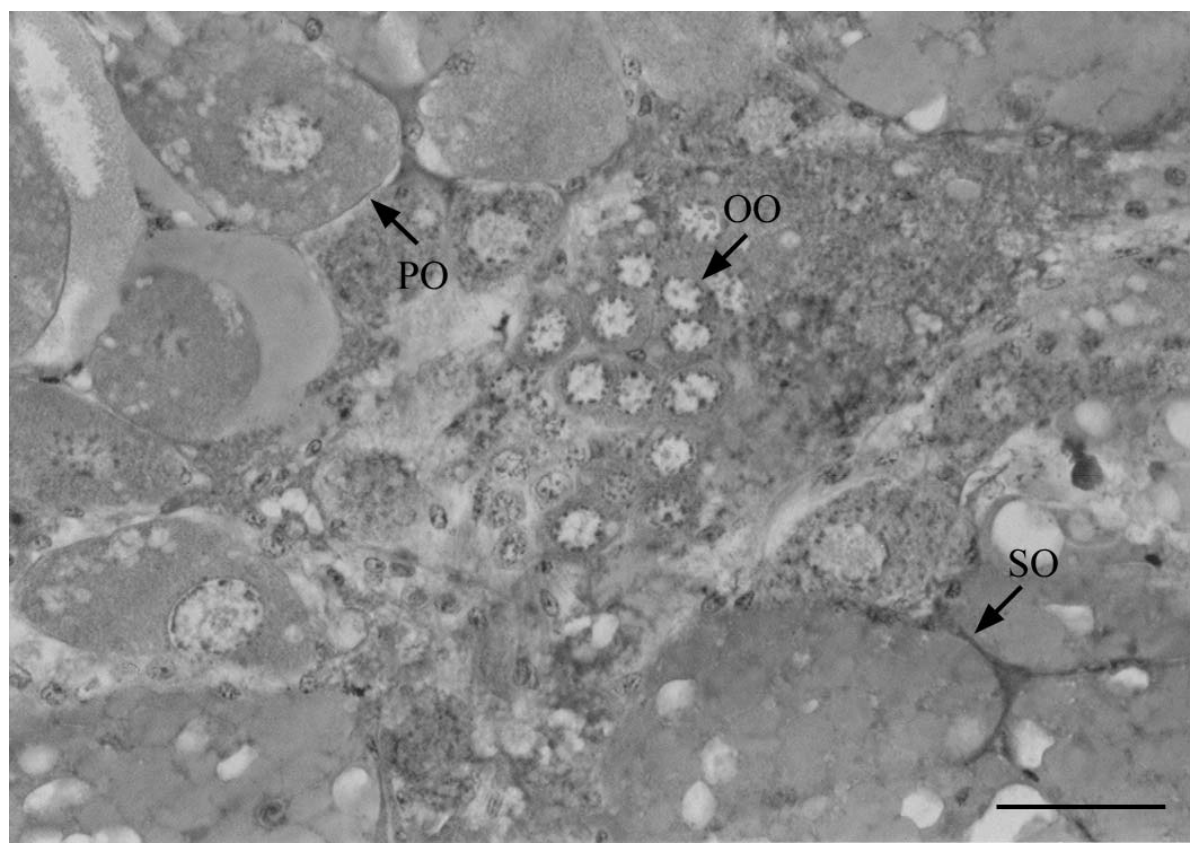

Fig. 1. Developing gonads of Uca rapax (Smith, 1870) showing the oogonias (OO), primary oocytes (PO) and secundary oocytes (SO). Bar, $0.04 \mathrm{~mm}$.

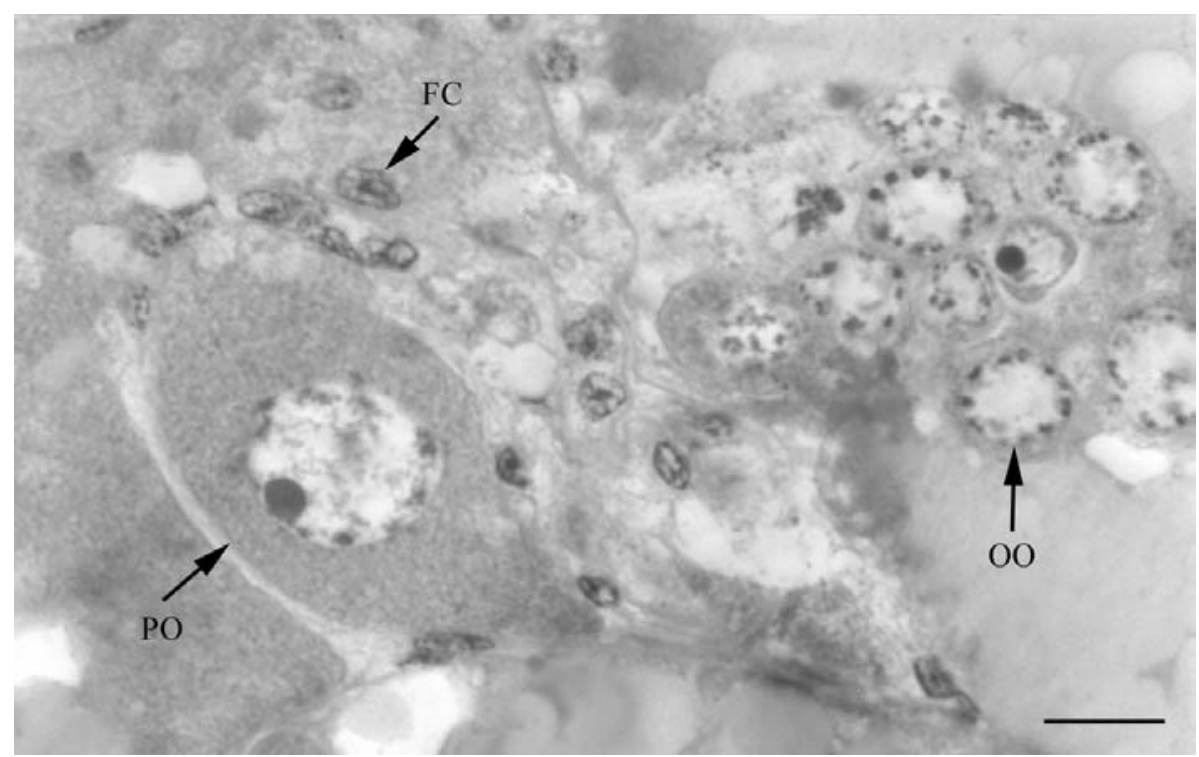

Fig. 2. Developing gonads of Uca rapax (Smith, 1870) showing the oogonias (OO), primary oocytes (PO) and some follicular cells (FC). Bar, $0.07 \mathrm{~mm}$. 


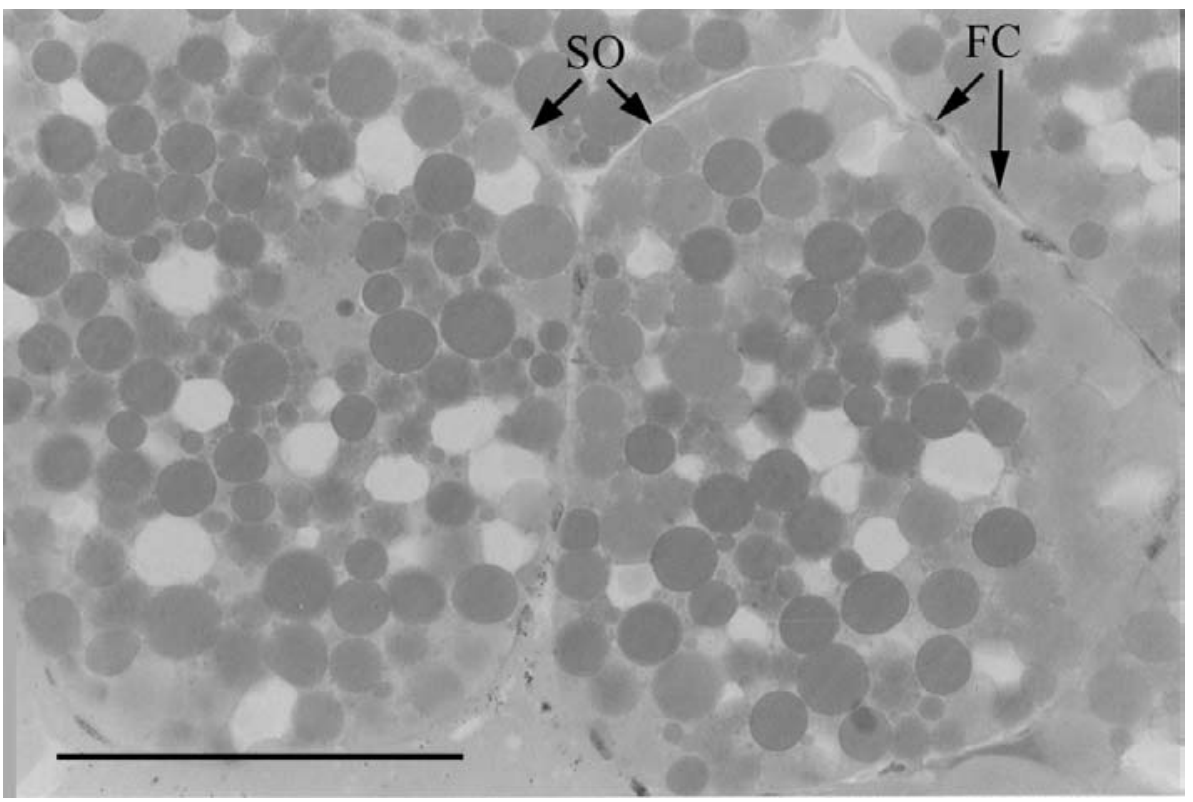

Fig. 3. Uca rapax (Smith, 1870): secundary oocytes (SO) surrounded by follicular cells (FC). Bar, $0.1 \mathrm{~mm}$.

oocytes, follicle cells with a round or oval shape start to surround the cells. Vitellogenic oocytes are abundant and present acidophilic cytoplasm, yolk, and lipid drops. Follicle cells surround the secondary oocytes forming a sheet of flat cells.

Advanced: ovary occupies the whole thoracic cavity, shows a lobate shape more pronounced than the observed in the previous stage, and a very dark red coloration. Gonad:hepatopancreas ratio is about 9:10. The gonad reaches its higher level of development, and its largest volume. This gonad stage is characterized by the abundance of mature secondary oocytes, and by the high number of vacuoles in the yolk. Oogonias and previtellogenic oocytes are rare. Vitellogenic oocytes are surrounded by flat follicle cells.

Spent: thin, flaccid, filamentous, transparent ovary. Gonad: hepatopancreas ratio is about 1:10. Oogonias and few primary oocytes are present.

It was not possible to describe microscopically the immature gonad due to its reduced size, which hindered the dissection and processing.

\section{DISCUSSION}

Ovaries color change during vitellogenesis is a common characteristic in crustaceans and has been recorded for Macrophthalmus hirtipes (Jacquinot, 1853), Crangon crangon Linnaeus, Callinectes danae Smith, 1869, Portunus spinimanus Latreille, and Cyrtograpsus angulatus Dana, 1851 by SimONs \& JONES (1981), HAEFNER \& Spaargaren (1983), Costa \& Negreiros-Fransozo (1998), Santos \& Negreiros-Fransozo (1999), and CAstiglioni \& SAntos (2001), respectively. This variation in coloration has been used to elaborate macroscopic scales in the ovarian development (ARCULEO et al., 1995; Pinheiro \& Fransozo, 1998; LóPEZ-Greco \& Rodríguez, 1999b; FLoREs et al., 2002). These scales allow a quick evaluation of the reproductive stage in a population in time and space, as well as the study of ovarian cycles in a species or population without performing histological analyses (ArCuleo et al., 1995; López-Greco \& RODRÍGUEZ, 1999b).

The ovaries of $U$. rapax showed a pronounced macroscopic differentiation in size and coloration during the maturation process of the gonad. During the vitellogenesis, the amount of oocytes in secondary stage increases in the ovary, resulting in a change in coloration of the gonad. According to CharniauX-CotTon (1980), ovary coloration is a result of the storage of vitellogenine presenting carotenoid pigments. According to BROWDY et al. (1990), the yolk is composed of water, proteins, and lipids, being an essential nutrient for the embryo development, a matrix for tissue formation, and a fuel for the new animal.

Three cellular stages of the gonad development of $U$. rapax were characterized in the present study: oogonias, pre-vitellogenic, and vitellogenic oocytes. The description of cellular stages agrees with the characteristics described by ADIYODI \& SUBRAMONIAN (1983) and Meusy \& Charniaux-Cotton (1984). These characteristics were posteriorly identified in other species of decapods (LóPEZ et al., 1997, ANDO \& MAKIOKA, 1998; ELORZA \& DuPRÉ, 2000).

According to Krol et al. (1992), the ovary germinative epithelium is located on the border or in the middle of the ovaries in decapod crustaceans. The oogonias and pre-vitellogenic oocytes are found in the middle region of the ovarian lobes, while the vitellogenic oocytes can be observed in the periphery. KING (1948) observed that the rapid multiplication of the central germinative cells pushes the first oocytes to the periphery of the ovarian lobes, which explains the occurrence of more developed oocytes in this region. This cellular arrangement was observed for U. rapax in the present work and also for Gecarcinus lateralis (Fréminville, 1835) (Weitzman, 1966), Pachygrapsus marmoratus (Fabricius, 
1787) (RouquetTe, 1970), Carcinus maenas (Linnaeus, 1758) (LAULIER, 1974), Chasmagnathus granulata Dana, 1851 (LóPEZ et al., 1997) and Penaeus penicillatus (Alcock, 1905) (Oliveira et al., 1999).

In the histological analyses of the female's ovaries, the modifications observed in the oocytes during the process of gonad maturation are similar to the descriptions in the literature for other females of decapod crustaceans (ADIYODI \& SUBRAMONIAN, 1983; LóPEZ et al., 1997; Oliveira et al., 1999; Ando \& MaKioka, 1998; Elorza \& Dupré, 2000). The similarities are specially found in the morphological changes in the reproductive cells, and also in the presence and arrange of follicle cells during the process of ovary maturation. Thus, the morphology and development of females' gonad has intensively been utilized as a tool for reproductive cycle studies.

When external morphological characteristics of the gonads were compared to histological descriptions, it was possible to observe modifications that characterize the process in different developmental stages throughout the ovarian cycle. Consequently, the macroscopic classification of gonad stages agrees with the modifications of the oocytes. However, the macroscopic differentiation between rudimentary and senescent gonads could demonstrate a significant difference, since in both stages the gonads present the same size, differing only in the flaccid appearance of the senescent gonad. On the other hand, the spent gonad is generally more voluminous than the immature gonad. In the histological analysis, the senescent gonad shows several oogonias, a small number of primary and secondary oocytes, and empty follicles. However, these cell types were not observed in immature ovaries. Thus, the macroscopic analysis of the size and coloration of gonads can be used to identify correctly the different stages of gonad development of females of $U$. rapax, since these stages showed also differences in their reproductive cells at the microscopic analysis.

Acknowledgments. To the Fundação de Amparo à Pesquisa no Estado de São Paulo for the fellowship to DSC (\#01/ 01810-9) and the financial support to the project (\#98/031346) conceded to MLNF; to NEBECC colleagues for their help during field and laboratory activities and to students of Laboratório de Histologia da Universidade Federal de Santa Maria for their help during histological processing. This work was accomplished according to state and federal laws concerning wild animal samplings.

\section{REFERENCES}

Abelló, P. 1989. Reproductive biology of Macropipus tuberculatus (Roux, 1830) in the northwestern Mediterranean. Ophelia 30(1):47-53.

Adiyodi, K. G. \& Subramonian, T. 1983. Arthopoda-Crustacea. In AdIYODI, K. G. ed. Reproductive biology of invertebrates: oogenesis, oviposition and oosorption. London, John Wiley and Sons. p.443-365.

Ando, H. \& MaKioka. T. 1998. Structure of the ovary and mode of oogenesis in a freshwater crayfish, Procambarus clarkii (Girard). Zoological Science 15:893-901.

Arculeo, M.; Payen, G.; Cuttitta, A.; Galioto, G. \& Riggio, S. 1995. A survey of ovarian maturation in a population of Aristaeus antennatus (Crustacea: Decapoda). Animal Biology 4:13-18.

Browdy, C. L., Fainzilber, M.; Tom, M.; Loya, Y. \& Lubzens, E. 1990. Vitellin synthesis in relation to oogenesis in vitro incubated ovaries of Penaeus semisulcatus. Journal of Experimental Zoology 255:5-215.

Castiglioni, D. S. \& Negreiros-Fransozo, M. L. 2004a. Comparative analysis of relative growth of Uca rapax (Smith) (Crustacea, Ocypodidae) from two mangroves in São Paulo, Brazil. Revista Brasileira de Zoologia 21(1):137-144.

2004 b. Somatic growth of the fiddler crab Uca rapax (Smith, 1870) (Brachyura, Ocypodidae) from two subtropical mangroves. Universidade y Ciencia 20(39):15-22.

2005. Comparative population biology of Uca rapax (Smith, 1870) (Brachyura, Ocypodidae) from Itamambuca and Ubatumirim mangroves in Ubatuba littoral, Brazil. Journal of Natural History 39(19):1627-1640.

2006. Physiologic sexual maturity of the fiddler crab Uca rapax (Smith, 1870) (Crustacea, Ocypodidae) from two mangroves in Ubatuba, Brazil. Brazilian Archives of Biology and Technology 49(2):239-248.

Castiglioni, D. S. \& SAntos, S. 2001. Reproductive aspects of Cyrtograpsus angulatus Dana, 1851 (Brachyura, Grapsidae) in the Lagoa do Peixe, Rio Grande do Sul State, Brazil. Nauplius 9(1):11-20.

Castiglioni, D. S.; Negreiros-Fransozo, M. L. \& Cardoso, R. C. F. 2006. Breeding season and molt cycle of the fiddler crab Uca rapax (Brachyura, Ocypodidae) in a subtropical estuary, Brazil, south America. Gulf and Caribbean Research 19:11-20.

Charniaux-Cotton, H. 1980. Experimental studies of reproduction in Malacostraca crustaceans. In: Clark, W. H. \& AdAms, T. S. eds. Description of vitellogenesis and of its endocrine control in Adv. Inv. Reprod. North Holland, Elsevier. p.177-185.

Choy, S. C. 1988. Reproductive biology of Liocarcinus puber and L. holsatus (Decapoda, Brachyura, Portunidae) from the Gower Peninsula, South Wales. Marine Biology 9(3):227-241.

Costa, T. M. C. \& Negreiros-Fransozo, M. L. 1998. The reproductive cycle of Callinectes danae Smith, 1869 (Decapoda, Portunidae) in the Ubatuba region, Brazil. Crustaceana 71(6):615-627.

Cronin, L. E. 1947. Anatomy and histology of the male reproductive system of Callinectes sapidus Rathbun. Journal of Morphology 81(2):209-239.

Dumont, L. F. C. \& D'InCAO, F. 2004. Stages of gonadal development in females of "barba-ruça" shrimp (Artemesia longinaris Decapoda, Penaeidae). Iheringia, Série Zoologia, 94(4):389-393.

Elorza, A. \& Dupré, E. 2000. Arquitectura del ovario de la langosta de Juan Fernández. Investigaciones Marinas 28: $175-194$.

Flores, A. A.; Saraiva, J. \& Paula, J. 2002. Sexual maturity, reproductive cycles, and juvenile recruitment of Perisesarma guttatum (Brachyura, Sesarmidae) at Ponta Rasa Mangrove swamp, Inhaca Island, Mozambique. Journal of Crustacean Biology 22:143-156.

Genoni, G. P. 1985. Food limitation in salt marsh fiddler crab Uca rapax (Smith) (Decapoda, Ocypodidae). Journal of Experimental Marine Biology and Ecology 87:97-110.

1991. Increased burrowing by fiddler crabs Uca rapax (Smith) (Decapoda: Ocypodidae) in response to low food supply. Journal of Experimental Marine Biology and Ecology 147:267-285.

Giese, A. C. \& Pearse, J. S. 1974. Introduction: General principles. In: Giese, A. C. \& PeARSE, J. S. eds. Reproduction of marine invertebrates. New York, Academic. p.1-49.

Goodwin, T. W. 1951. Carotenoid metabolism during development of lobster eggs. Nature 449:559.

Greenspan, B. N. 1980. Male size and reproductive success in the communal courtship system of the fiddler crab Uca rapax. Animal Behavior 28:387-392.

HAEFNER JR., P. A. 1976. Distribution, reproduction and moulting of the rock crab, Cancer irroratus Say, 1917 in the midAtlantic bight. Journal of Natural History 10:377-397.

Haefner, P. A. \& SpaArgaren, D. H. 1983. Interactions of ovary and hepatopancreas during the reproductive cycle of Crangon crangon (L). 1. Weight and volume relationships. Journal of Crustacean Biology 13(3):523-531.

KING, J. E. 1948. A study of the reproductive organs of the common shrimp Penaeus setiferus (Linnaeus). Biological Bulletin 94:224-262. 
Krol, R. M.; Hawkins, W. E. \& Overstreet, R. M. 1992. Reproductive components. In: Harrison, F. W. \& Humes, A. G. eds. Microscopic anatony of invertebrates. v. 10. New York, Wiley-Liss. p.295-344.

LAulier, M. 1974. Caractères cytologique de la cellule sexuelle femele du crabe Carcinus maenas L. au cours de la gamétogenése. Cahiers de Biologie Marine 2:159-167.

LóPez-Greco, L. S. \&. Rodríguez, E. M. 1999a. Size at the onset of sexual maturity in Chasmagnathus granulata Dana, 1851 (Grapsidae, Sesarminae): a critical overall view about the usual criteria for its determination. In: Schram, R. \& Vauplen, K. F. eds. Crustaceans and the biodiversity crisis. Leiden. p.676-689.

1999b. Annual reproduction and growth of adult crabs Chasmagnathus granulata (Brachyura, Grapsidae). Cahiers de Biologie Marine 40:155-164.

López, L. S. G.; Stella, V. S. \& Rodríguez, E. M. 1997. Size at onset of sexual maturity in Chasmagnathus granulata (Decapoda, Brachyura). Nauplius 5(2):65-75.

McNamara, J. C. \& Moreira, G. S. 1983. Ultrastructure of chromatophores from the fiddler crabs Uca rapax (Smith) and Uca uruguayensis (Nobili) (Decapoda, Brachyura). Crustaceana 44:301-309.

Melo, G. A. S. 1996. Manual de identificação dos Brachyura (caranguejos, siris) do litoral brasileiro. São Paulo, Plêiade, FAPESP. 603p.

Meusy, J. J. \& Charniaux-Cotton, H. 1984. Endocrine control of vitellogenesis in Malacostraca crustaceans. In: ENGELs, W. ed. Advances in invertebrate reproduction. Amsterdam, Elsevier Science. p.231-242.

Moraes, N. 1994. Aspectos morfológicos e histoquímicos da gônada masculina de Macrobrachium rosembergii (De Man, 1896) (Crustacea, Decapoda, Palaemonidae). Brazilian Archives of Biology and Technology 38(3):679-688.

Mossolin, E. C. \& Bueno, S. L. S. 2002. Reproductive biology of Macrobrachium olfersi (Decapoda, Palaemonidae) in São Sebastião, Brazil. Journal of Crustacean Biology 22(2):367-376

Negreiros-Fransozo, M. L.; Fransozo, A. \& Bertini, G. 2002. Reproductive cycle and recruitment period of Ocypode quadrata (Decapoda, Ocypodidae) at a sandy beach in southeastern Brazil. Journal of Crustacean Biology 22(1): 157-161

Oliveira, P. S. P.; Santos, G. V. \& CorrêA, A. M. A. 1999. O desenvolvimento ovocitário em Penaeus penicillatus (Alcock, 1905), submetidos a monoablação do pedúnculo ocular. Nauplius 7:53-64.

Palacios, E.; Perez-Rostro, C. I.; Ramirez, J. L.; Ibarra, A. M. \& Racotta, I. S. 1999. Reproductive exhaustion in shrimp (Penaues vannamei) refleted in larval biochemical composition, survival and growth. Aquaculture 171:309-312.

Pinheiro, M. A. A. \& Fransozo, A. 1998. Sexual maturity of the speckled swimming crab Arenaeus cribrarius (Lamarck, 1818) (Decapoda, Brachyura, Portunidae), in the Ubatuba littoral, São Paulo State, Brazil. Crustaceana 71(4):435-452.

Quinitio, E. T. \& Millamena, O. M. 1992. Ovarian changes and female-specific protein levels during sexual maturation of the white shrimp Penaeus indicus. The Israeli Journal of Aquaculture 44(1):7-12.
Quintero, M. E. S. \& Gracia, A. 1998. Stages of gonadal development in the spotted pink shrimp Penaeus brasiliensis. Journal of Crustacean Biology 18(4):680-685.

Rodríguez, A. 1985. Biología del langostino Penaeus kerathurus (Forskal, 1775) del golfo de Cádiz. I. Reproducción. Investigaciones Pesqueras 49(4):581-595.

Rouquette, M. 1970. Etude di tissu overien chez le crabe Pachygrapsus marmoratus (Fabricius). Premiers résultate concernant les rôles de la temperature et des péduncules oculares. Bulletin de la Societe Zoologique de France 95(2): 233-240.

SAKAJI, H. 2001. Maturation and spawning of the small penaeid shrimp Metapenaeopsis dalei in Tosa Bay, Pacific coast of southern Japan. Fisheries Science 67:444-448

Sakaji, H.; Tsuchiya, K. \& Segawa, S. 2000. Oocyte development of Metapenaeopsis dalei (Penaeidae, Decapoda, Crustacea). Invertebrate and Reproduction Development 38:7-12.

Salmon, M. 1971. Signal characteristics and acoustic detection by fiddler crabs, Uca rapax and Uca pugilator. Physiological Zoology 44(4):210-221.

SAlmon, M. \& Kettler, M. K. 1987. The importance of behavioral and biochemical differences between fiddler crab taxa, with special reference to Uca rapax (Smith) and U. virens (Salmon and Atsaides). Contributions in Marine Science 30:63-76.

Santos, S. \& Negreiros-Fransozo, M. L. 1999. Reproductive cycle of the swimming crab Portunus spinimanus Latreille (Crustacea, Decapoda, Brachyura) from the Ubatuba, São Paulo, Brazil. Revista Brasileira de Zoologia 16(4):11831193.

SASTRY, A. N. 1983. Ecological aspects of reproduction. In: Vernberg, F. J. \& Vernberg, W. B. eds. The biology of Crustacea: environmental adaptations. v. 8, New York, Academic. p.179-269.

Simons, M. J. \& Jones, M. B. 1981. Population and reproductive biology of the mud crab Macrophthalmus hirtipes (Jacquinot, 1853) (Ocypodidae), from marine and estuarine habitats. Journal of Natural History 15:981-994.

Swiney, K. M. \& Shirley, T. C. 2001. Gonad development of southeastern Alaskan Dungeness crab, Cancer magister, under laboratory conditions. Journal of Crustacean Biology 21(4):897-904.

Tan-Fermin, J. D. \& Pudadera, R. A. 1989. Ovarian maturation stages of the wild giant tiger prawn, Penaues monodon Fabricius. Aquaculture 77:229-242.

Weitzman, M. C. 1966. Oogenesis in the topical land crab Gecarcinus lateralis (Freminville). Zeitschrift fur Zellforschung und Mikroskopische Anatomie 75:109-119.

Wenner, E. L.; Ulrich, G. F. \& Wise, J. B. 1987. Exploration for golden crab Gerion fenneri, in the south Atlantic bight: distribution, population structure and gear assessment. Fishery Bulletin 85(3):547-560.

ZANDERS, I. P. \& RoJAs, W. E. 1996a. Transbranchial potentials and ion fluxes across isolated, perfused gills of Uca rapax. Marine Biology 125:307-314.

1996b. Osmotic on ionic regulation in the fiddler crab Uca rapax acclimated to dilute and hypersaline seawater. Marine Biology 125:315-320.

1996c. Salinity effects on Cadmium accumulation in various tissues of the tropical fiddler crab Uca rapax. Environmental Pollution 96(3):293-299.

Recebido em agosto de 2006. Aceito em julho de 2007. ISSN 0073-4721

Artigo disponível em: www.scielo.br/isz 